\title{
Patterns of Proinflammatory Cytokines and Inhibitors during Typhoid Fever
}

\author{
Monique Keuter, Edi Dharmana, M. Hussein Gasem, \\ Johanna van der Ven-Jongekrijg, \\ Robert Djokomoeljanto, Wil M. V. Dolmans, \\ Pierre Demacker, Robert Sauerwein, Harald Gallati, \\ and Jos W. M. van der Meer
}

\author{
University Hospital. Nijmegen, Netherlands; Diponegoro University. \\ Semarang, Indonesia; F. Hoffman-LaRoche, Basel, Switzerland
}

\begin{abstract}
Cytokines and inhibitors in plasma were measured in 44 patients with typhoid fever. Ex vivo production of the cytokines was analyzed in a whole blood culture system with and without lipopolysaccharide (LPS). Acute phase circulating concentrations of cytokines $( \pm \mathrm{SD}$ ) were as follows: interleukin (IL)-1 $\beta,<140 \mathrm{pg} / \mathrm{mL}$; tumor necrosis factor- $\alpha$ (TNF $\alpha), 130 \pm 50 \mathrm{pg} / \mathrm{mL}$; IL-6, $96 \pm 131 \mathrm{pg} / \mathrm{mL}$; and IL-8, $278 \pm 293 \mathrm{pg} / \mathrm{mL}$. Circulating inhibitors were elevated in the acute phase: IL-1 receptor antagonist (IL-1RA) was $2304 \pm 1427 \mathrm{pg} / \mathrm{mL}$ and soluble TNF receptors 55 and 75 were $4973 \pm 2644 \mathrm{pg} / \mathrm{mL}$ and $22,865 \pm 15,143 \mathrm{pg} / \mathrm{mL}$, respectively. LPSstimulated production of cytokines was lower during the acute phase than during convalescence (mean values: IL-1 $\beta, 2547$ vs. $6576 \mathrm{pg} / \mathrm{mL}$; TNF $\alpha, 2609$ vs. $6338 \mathrm{pg} / \mathrm{mL}$; IL-6, 2416 vs. 7713 $\mathrm{pg} / \mathrm{mL}$ ). LPS-stimulated production of IL-1RA was higher in the acute than during the convalescent phase ( 5608 vs. $3977 \mathrm{pg} / \mathrm{mL}$ ). Inhibited production of cytokines during the acute phase may be due to a switch from a proinflammatory to an antiinflammatory mode.
\end{abstract}

Typhoid fever is caused by the facultative intracellular gram-negative bacillus Salmonella typhi and occasionally by Salmonella paratyphi. Although salmonellae contain lipopolysaccharide (LPS; bacterial endotoxin), the clinical picture of typhoid fever differs from gram-negative sepsis, and the role of endotoxin in the pathophysiology of typhoid fever is controversial [1].

The proinflammatory cytokines interleukin (IL)-1 $\beta$, tumor necrosis factor- $\alpha$ (TNF $\alpha$; cachectin), IL-6, and IL-8 have been implicated in the pathogenesis of sepsis caused by gram-negative microorganisms [2-4]. When LPS is injected intravenously into animals or human volunteers, elevated concentrations of these cytokines can be detected, and the symptoms and signs of sepsis are mimicked [5-7]. Elevated circulating levels of TNF $\alpha$ have been correlated with poor prognosis in sepsis, meningococcemia, and cerebral malaria [7-10]. In contrast, in infections with intracellular pathogens, such as Leishmania species, Listeria monocytogenes, or mycobacteria, administration of TNF $\alpha$ inhibits the outgrowth of the microorganisms, whereas administration of an-

Received 13 September 1993; revised 12 January 1994.

Presented in part: Third International Workshop on Cytokines, Sienna, Italy, 10-14 November 1991.

Patients gave informed consent, and guidelines for human experimentation of the Dr. Kariadi Hospital, Diponegoro University, were followed.

Grant support: Scientific Research in the Tropics, Netherlands Foundation for Science.

Reprints or correspondence: Dr. Monique Keuter, University Hospital. Dept. of Internal Medicine, P.O. Box 9101, 6500 HB Nijmegen, Netherlands.

The Journal of Infectious Diseases 1994;169:1306-11 (C) 1994 by The University of Chicago. All rights reserved. $0022-1899 / 94 / 6906-0017 \$ 01.00$ tibodies to this cytokine are detrimental [11-16]. In experimental Salmonella typhimurium infection in mice, the role of $\mathrm{TNF} \alpha$ is similar to that in other intracellular infections [17-19]. However, in calves with $S$. typhimurium sepsis, the cytokine pattern appears to differ from that seen after intravenously administered LPS. Where TNF $\alpha$ rose $1 \mathrm{~h}$ after LPS administration, salmonella sepsis caused a barely detectable increase in $\mathrm{TNF} \alpha[20]$.

In contrast to these animal studies, circulating cytokines (TNF $\alpha$, IL-6, and IL-1 $\beta$ ) were elevated in children with typhoid fever in Chile [21]. Butler et al. [22] studied the outcome of typhoid fever in adults in Nepal and found that higher values of IL- 6 and soluble TNF receptor p55 were related to poorer outcome.

In 1989, joint research on several aspects of typhoid fever was started between Nijmegen University and Diponegoro University. To obtain more insight into the pathophysiology of typhoid fever, we measured levels of circulating pyrogenic cytokines (IL-1 $\beta$, TNF $\alpha$, TNF $\beta$ [lymphotoxin], and IL-6) and concentrations of IL-8, the cytokine inhibitor IL-I receptor antagonist (IL-IRA), and the soluble TNF receptors p55 and 75 (sTNF-R). In addition, we investigated the capacity of blood cells to produce IL-1 $\beta, \mathrm{TNF} \alpha$, IL-6, and IL1 RA ex vivo in the acute and convalescent phases of hospitalized patients with typhoid fever.

We used the whole blood cytokine test as described by van Deuren et al. [23] and Nerad et al. [24]. This assay is simple, reproducible, and especially suitable for use in laboratories that are not particularly well equipped for work with cytokines. In addition, the method may be less artificial than is isolating mononuclear cells over a gradient and probably is a more natural mirror of what happens in vivo, because plasma factors and other cells are left in situ. 
Table 1. Characteristics of 44 hospitalized culture-proven typhoid fever patients.

\begin{tabular}{lcc}
\hline Characteristic & Complicated disease & Uncomplicated disease \\
\hline No. of patients & 16 & 28 \\
Mean age (range), years & $20(14-34)$ & $24(14-60)$ \\
Males/females & $7 / 9$ & $12 / 16$ \\
Median (range) of & & \\
$\quad$ days with fever & & $8.5(4-30)$ \\
before admission & $10.0(4-20)$ & \\
Leukocyte count at & & - \\
$\quad$ admission (range) & $7.3 \times 10^{9} / \mathrm{L}(2.6-37.0)$ & $4.4 \times 10^{9} / \mathrm{L}(1.6-7.4)$ \\
Complications & 16 & - \\
Pneumonia & 10 & \\
Delirium & 2 & \\
Perforation & 5 & \\
Bleeding & 1 & \\
\hline
\end{tabular}

\section{Patients and Methods}

The study was done in Dr. Kariadi Hospital, Diponegoro University, Semarang, Indonesia, beginning in December 1990. Blood and bone marrow cultures were done for all adult patients (>14 years old) hospitalized with suspected typhoid fever (defined as fever $>38.5^{\circ} \mathrm{C}$ and at least one of the following signs: relative bradycardia, abdominal complaints, mental changes, signs of complicated typhoid fever, enlarged liver or spleen and no apparent other disease). If blood or bone marrow cultures were positive for $S$. typhi or $S$. paratyphi A or patients were found to have perforated ilea at surgical exploration, typhoid fever was considered proven.

A total of 44 patients were studied. Patient characteristics are shown in table 1. Complications of typhoid fever were defined as gastrointestinal bleeding, intestinal perforation, shock, delirium, stupor or coma, pneumonia, or diffuse intravascular coagulation.

Treatment consisted of chloramphenicol (40 $\mathrm{mg} / \mathrm{kg} /$ day orally) if leukocyte counts were $>2 \times 10^{\mathrm{g}} / \mathrm{L}$. If fever did not subside within 6 days, treatment was changed to sulfamethoxazole $(800 \mathrm{mg})$ and trimethoprim $(160 \mathrm{mg})$ twice daily or ampicillin ( $1 \mathrm{~g}$ four times daily). Surgical patients received ampicillin, metronidazole, and gentamicin during and after surgery. No cyclooxygenase inhibitors were given. Only 2 patients received a single dose of $120 \mathrm{mg}$ of dexamethasone, but not before blood was obtained for cytokine measurement. Most patients were discharged $7-10$ days after defervescence, which we defined as convalescence. No patients died.

Cytokine measurements. On admission and during convalescence, blood was drawn for cytokine measurement. Venous blood samples were aseptically collected into sterile 4-mL tubes (Vacutainer; Becton Dickinson, Rutherford, $\mathrm{NJ}$ ) containing EDTA. Unless stated otherwise, a total of 3 tubes of blood was drawn from each patient [23]. To each tube, $250 \mu \mathrm{L}$ of aprotinin (Trasylol 2500 kallikreine inactivating units [KIU]; Bayer, Leverkusen. Germany; final concentration $625 \mathrm{KJU} / \mathrm{mL}$ ) was added through the stopper by a tuberculin needle and syringe. One tube was centrifuged directly $(1250 \mathrm{~g}, 10 \mathrm{~min})$, platelets from the supernatant plasma were removed by a second centrifu- gation $(15,000 \mathrm{~g}, 1 \mathrm{~min})$, and plasma was collected and stored at $-20^{\circ} \mathrm{C}$ until assayed for cytokines. To one of the two remaining tubes, $50 \mu \mathrm{L}$ of LPS (Escherichia coli serotype 055:B5; Sigma, St. Louis; final concentration $10 \mu \mathrm{g} / \mathrm{mL}$ ) was added to stimulate cytokine production. Unstimulated samples contained aprotinin only (no LPS). Both tubes were incubated at $37^{\circ} \mathrm{C}$ for $24 \mathrm{~h}$.

For 17 (random) patients, a fourth 4-mL tube of blood was obtained in the acute phase in to which indomethacin was added $(0.5 \mu \mathrm{g} / \mathrm{mL}$ final concentration). For 26 (random) patients, we obtained a total of six tubes of blood. From two of these, we removed the plasma, replacing it with a like amount of PBS.

TNF $\alpha$ was determined by an RIA (detection level $100 \mathrm{pg} /$ $\mathrm{mL}$ ), described in [25]. Normal TNF $\alpha$ values for our laboratory (circulating concentrations and ex vivo production without LPS below the detection limit and ex vivo production after $24 \mathrm{~h}$ of stimulation with LPS) are $3780 \pm 950 \mathrm{pg} / \mathrm{mL}$.

IL- $1 \beta$ was measured by RIA according to the method of Lisi et al. [26] but without chloroform extraction (detection level $140 \mathrm{pg} / \mathrm{mL}$ ). Normal values for our laboratory (circulating concentrations and ex vivo production without LPS below the detection limit and ex vivo production after $24 \mathrm{~h}$ of stimulation with LPS) are $6930 \pm 3160 \mathrm{pg} / \mathrm{mL}$.

IL-6 was measured by an ELISA as described (detection level, $20 \mathrm{pg} / \mathrm{mL}$ ) [27]. Normal values for our laboratory (circulating concentrations and ex vivo production without LPS) were below the detection limit.

IL-8 was measured by ELISA quantikine ( $R$ \& D Systems, Europe, Abingdon, UK). The detection limit was $45 \mathrm{pg} / \mathrm{mL}$, and normal values were below the detection limit. We sought TNF $\beta$ (lymphotoxin) by ELISA quantikine (R \& D Systems, Europe) but failed to detect any. IL-IRA was determined by an RIA according to the method of Poutsiaka et al. [28] (detection level $300 \mathrm{pg} / \mathrm{mL}$ ). Normal values for our laboratory (circulating concentrations and ex vivo production without LPS below the detection limit, ex vivo production after $24 \mathrm{~h}$ stimulation with LPS) were $5757 \pm 1060 \mathrm{pg} / \mathrm{mL}$.

sTNF-R was measured by an enzyme-linked immunobinding assay (Hoffman-La Roche, Basel, Switzerland; detection level, 80 and $300 \mathrm{pg} / \mathrm{mL}$ for $\mathrm{p} 55$ and p75, respectively). Normal values for circulating concentrations are $1.50 \mathrm{ng} / \mathrm{mL}(\mathrm{p} 55)$ and $2.51 \mathrm{ng} / \mathrm{mL}$ ( 75 ). All samples from the same patient were analyzed in the same run in duplicate to minimize analytical errors.

Statistics. When frequency distribution was parametric, we used paired and unpaired Student's $t$ test. When not parametric, Wilcoxon signed-rank test or Mann-Whitney $U$ test was used. $P$ $<.05$ was considered significant.

\section{Results}

Circulating cytokines and inhibitors during acute and convalescent phases of typhoid fever. Concentrations of pyrogenic cytokines during the acute phase (IL-1 $\beta$, IL-6, TNF $\alpha$, lymphotoxin) are shown in figure 1 . IL- $1 \beta$ concentrations were below the detection limit in both acute and convalescent phases. IL -6 concentrations ranged from undetectable $(<20$ $\mathrm{pg} / \mathrm{mL}$ ) to $600 \mathrm{pg} / \mathrm{mL}$ (median, 73). TNF $\alpha$ concentrations ranged from below the detection limit to $310 \mathrm{pg} / \mathrm{mL}$ (me- 


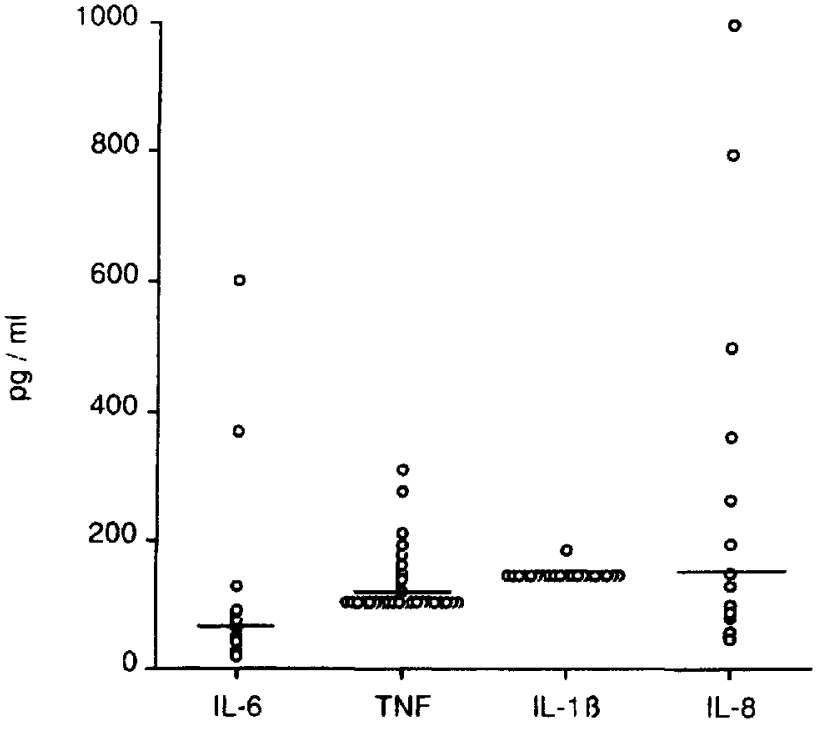

Figure 1. Circulating concentrations of pyrogenic cytokines interleukin (IL)- $1 \beta$, tumor necrosis factor (TNF)- $\alpha$, IL-6, and IL-8 in patients during acute phase of typhoid fever. Patients had been ill $>$ I week. Horizontal continuous circles $=$ detection limit; horizontal bars $=$ median values. In comparison with normal values, IL-6. IL-8, and TNF $\alpha$ are slightly elevated.

dian, 110) in the acute phase and to $300 \mathrm{pg} / \mathrm{mL}$ (median, below detection limit) during the convalescent phase. All lymphotoxin concentrations were below detection limits during acute and convalescent phases. IL- 8 concentrations were detectable in the acute phase (median, 145; range, 47$998 \mathrm{pg} / \mathrm{mL}$ ) but lower during the convalescent phase (median, 46; range, $46-180 \mathrm{pg} / \mathrm{mL}$ ).

Inhibitors such as IL-1RA and sTNF-R (p55 and p75) were significantly higher in the acute phase than during the convalescent phase: IL-IRA, $2304 \pm 1427 \mathrm{pg} / \mathrm{mL}$ versus $469 \pm 324 \mathrm{pg} / \mathrm{mL}$; sTNF-R $55,4973 \pm 2644 \mathrm{pg} / \mathrm{mL}$ versus $1671 \pm 532 \mathrm{pg} / \mathrm{mL}$; and sTNF-R75, 22,865 $\pm 15,143 \mathrm{pg} /$ $\mathrm{mL}$ versus $5971 \pm 2750 \mathrm{pg} / \mathrm{mL}$ (figure 2 ).
Circulating cytokines and inhibitors in complicated and uncomplicated disease. No differences were found in circulating cytokines or inhibitors between the 16 patients with complicated and the 28 patients with uncomplicated disease courses.

Ex vivo production of cytokines and inhibitors during acute and convalescent phases. Unstimulated whole blood cultures did not have detectable IL-1 $\beta$, TNF $\alpha$, or IL-6 (not shown). After incubation with LPS for $24 \mathrm{~h}$, the supernatants contained detectable amounts of these cytokines, which were significantly lower in the acute phase than in convalescence (IL-1 $\beta$ : $2547 \pm 3319$ vs. $6576 \pm 6275 \mathrm{pg} / \mathrm{mL}, P<$ .001 ; TNF $\alpha: 2609 \pm 2443$ vs. $6338 \pm 4366 \mathrm{pg} / \mathrm{mL}, P<$ .001 ; IL-6: $2416 \pm 1531$ vs. $7713 \pm 3809 \mathrm{pg} / \mathrm{mL}, P=.01$; figure 3).

In the acute phase, there was a correlation between the LPS-stimulated production of IL- $1 \beta$ and TNF $\alpha(r=.664)$, IL-1 $\beta$ and IL-6 $(r=.531)$, and TNF $\alpha$ and IL-6 $(r=.434)$. Such correlations were not found during convalescence.

When indomethacin was added to the stimulated samples, the concentrations of TNF $\alpha$ and IL-1 $\beta$ in the acute phase were not different from those without indomethacin (2859 \pm 2630 vs. $2609 \pm 2443$ and $2782 \pm 2821$ vs. $2547 \pm 3319$ $\mathrm{pg} / \mathrm{mL}$ for TNF $\alpha$ and IL- $1 \beta$, with and without indomethacin, respectively). Also, removal of plasma and replacement with PBS did not change the stimulated production of TNF $\alpha$ and IL- $1 \beta$ in the acute phase (TNF $\alpha: 3307 \pm 3920 \mathrm{pg} / \mathrm{mL}$; IL- $1 \beta: 2244 \pm 2512 \mathrm{pg} / \mathrm{mL}$ ).

The IL-1RA concentrations found in unstimulated cultures (not shown) were similar to those during the acute phase. However, the LPS-stimulated production of IL-1RA was high and reached significantly higher concentrations in the acute phase of the disease $(5608 \pm 1832 \mathrm{pg} / \mathrm{mL})$ than during convalescence $(3977 \pm 1974 \mathrm{pg} / \mathrm{mL} ; P<.05)$. sTNF$\mathrm{R}, \mathrm{IL}-8$, and lymphotoxin were not generated in the cultures.

Ex vivo production of cytokines and inhibitors during complicated and uncomplicated courses of disease. In the acute
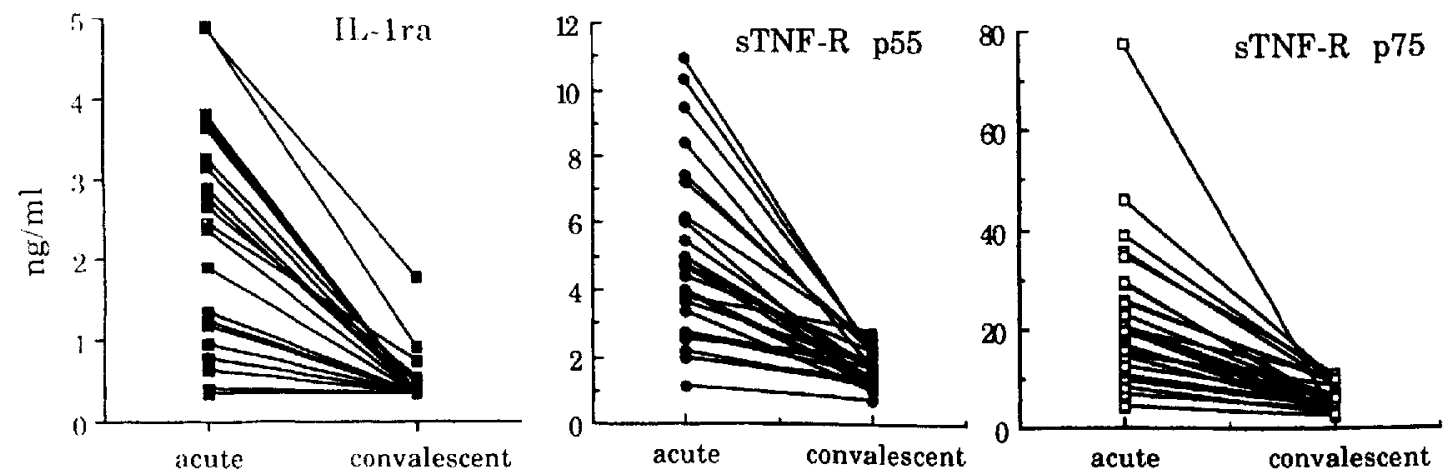

Figure 2. Individual concentrations of circulating interleukin (IL)-I receptor antagonist (ra) and tumor necrosis factor (sTNF-R) soluble receptors 55 and 75 in patients during acute and convalescent phases of typhoid fever. Inhibitors like IL-Ira and sTNF-R (p55 and p75) were significantly higher in acute phase than during convalescent phase. 

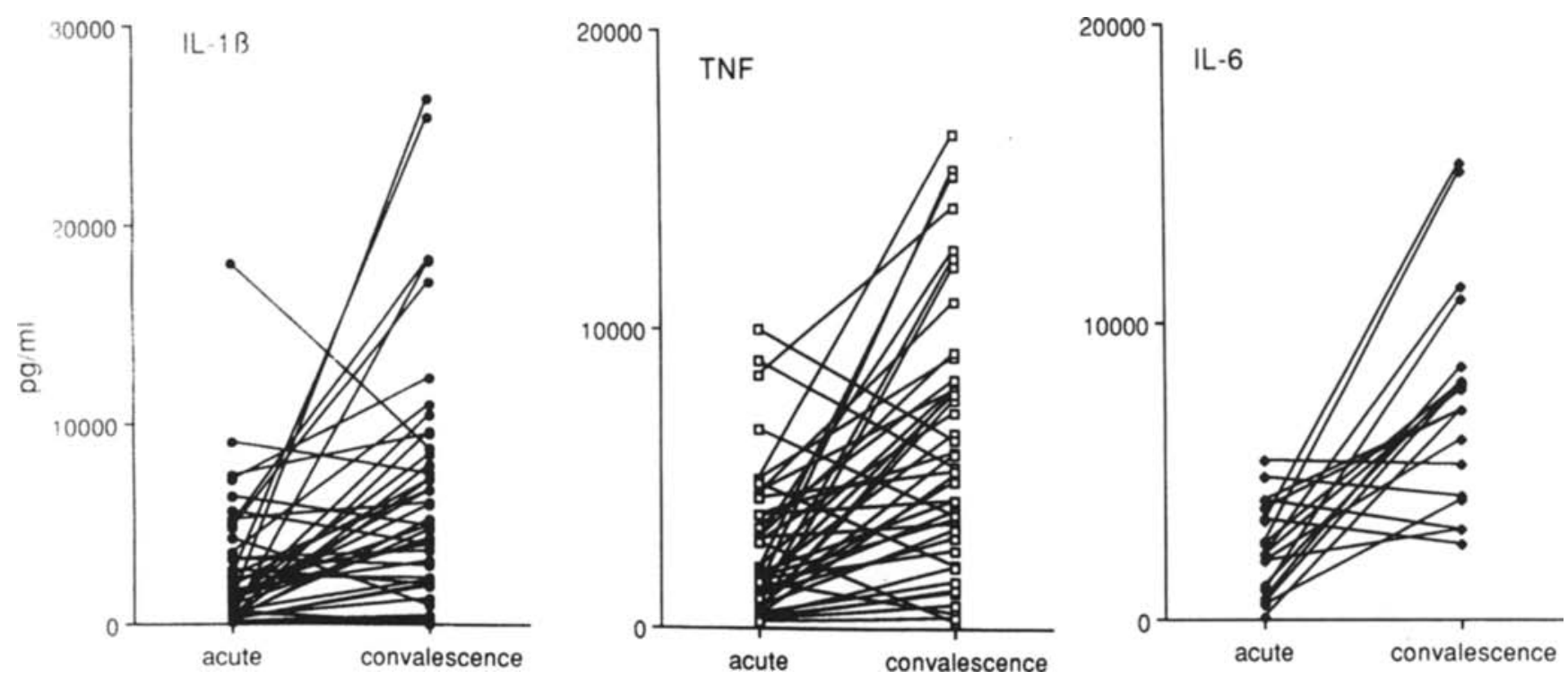

Figure 3. Individual production capacity of interleukin (IL)-1 $\beta$, tumor necrosis factor (TNF)- $\alpha$, and IL-6 in acute and during convalescent phases of typhoid fever. After incubation with lipopolysaccharide for $24 \mathrm{~h}$, supernatants contained detectable amounts of cytokines, which were significantly lower in acute phase than during convalescence.

phase, patients with complicated disease had significantly less $I L-1 \beta$ production after ex vivo stimulation with LPS $(1341 \pm 1373$ vs. $6563 \pm 1342 \mathrm{pg} / \mathrm{mL} ; P<.005)$ and a trend towards lower TNF $\alpha$ production ( $1650 \pm 1407$ vs. $3064 \pm$ $2770 \mathrm{pg} / \mathrm{mL} ; P=.06$ ). Such differences were not found for the production of IL-1RA or IL-6. During the convalescent phase, the ex vivo-stimulated production of IL-1 $\beta$ and $\mathrm{TNF} \alpha$ did not differ for complicated and uncomplicated cases of disease.

\section{Discussion}

In this study we found several signs of cytokine activation during typhoid fever. The concentrations of circulating inhibitors such as IL-1RA and sTNF-R were high in the acute phase of the disease. IL-1RA is known not to be detectable in the circulation of normal subjects. Normal values for sTNF$\mathrm{R}$ are $1.50 \mathrm{ng} / \mathrm{mL}$ (p55) and $2.51 \mathrm{ng} / \mathrm{mL}$ (p75) [29,30]. We also found that the production capacity of pyrogenic cytokines in whole blood is depressed in the acute phase of typhoid fever but is restored during the convalescent phase. Although the patients in our study usually had severe typhoid fever, we found that those with complicated disease courses had significantly lower proinflammatory cytokine production capacity than did those with uncomplicated disease.

A low production capacity of cytokines has been found in other serious conditions, such as severe postoperative infection [31], sepsis [32-34], and attacks of familial Mediterranean fever $[35,36]$. In these reports, all investigators used isolated peripheral blood mononuclear cells or tissue macro- phages. We have previously found depressed cytokine production capacity in the whole blood culture system during the acute phase of meningococcal disease and during Pneumocysis carinii infection (unpublished data). From these studies and the work presented here, we conclude that the depressed cytokine production capacity is not a consequence of fewer white blood cells during the acute phase of the infection, since we found no correlation between leukocyte count and cytokine production (table 1).

Many investigators [31-36] have interpreted the finding of low cytokine production capacity as exhaustion of cytokineproducing cells, which could be a consequence of exposure in vivo to stimuli such as endotoxin. Our finding that ILIRA is produced in high concentrations argues against such a hypothesis and also rules out the possibility that the decreased production of proinflammatory cytokines is due to an enhanced lysis of producing cells or to increased inactivation of LPS by lipids in the acute phase. Although we have been unable to demonstrate that the proinflammatory cytokines and IL-I RA are produced by the same kind of cells, we hypothesize that after the initial phase of infection, cytokineproducing cells switch from a balanced proinflammatory to an antiinflammatory repertoire. Our findings that patients in the acute phase of typhoid fever have high concentration of soluble sTNF-Rs in their blood is in agreement with this notion.

Since our cultures used whole blood, we investigated whether some common circulating factor could be responsible for the correlated low production capacity of the cytokines IL-1 $\beta$, TNF $\alpha$, and IL- 6 in the acute phase. Cyclooxygenase products, such as prostaglandin $E_{2}$, which inhibit 
production of IL-1 and TNF $\alpha$ [37], were not responsible since addition of indomethacin to the whole blood cultures did not lead to significant changes in cytokine production. Likewise, removal of plasma and addition of saline before incubation did not overcome the suppression in the acute phase of the disease.

It is possible that exposure in vivo to other inhibitory factors will explain the low cytokine production capacity. Schindler et al. [38] demonstrated that exposure of isolated mononuclear cells to IL-6 inhibits the production of IL-1 and TNF $\alpha$. In the present study, we found no correlation between IL- 6 concentrations in plasma and the magnitude of the production of IL- $1 \beta$ and TNF $(r=.041$ and .035 , respectively). Exposure to other cytokines such as, IL-4, IL-10, and transforming growth factor $\beta$ could, however, play a role. Vannier et al. [39] have provided evidence that exposure of cells to IL-4 suppresses the IL-1 production but up-regulates the synthesis of IL-1RA.

With few exceptions, patients with typhoid fever have a continuous fever. Hence, pyrogenic cytokines would be expected to be present in the circulation during the acute phase of the disease. In our series of febrile patients with typhoid fever, we could not detect appreciable concentrations of the pyrogenic cytokines IL-1 $\beta$, TNF $\alpha$, and lymphotoxin. The concentrations of IL-6, generally considered a relatively weak pyrogen [40], were low compared to findings with other febrile conditions $[3,41]$. We did detect elevated concentrations of IL-8, but this cytokine is considered nonpyrogenic [42].

Thus, the question of which pyrogens are responsible for the continuous fever in typhoid fever remains unanswered.

\section{Acknowledgment}

We thank James Vannice (Synergen, Boulder, CO) for supplying reagents for IL-IRA measurements.

\section{References}

1. Greisman SE, Hornick RB, Wagner HN Jr, Woodward WE, Woodward TE. The role of endotoxin during typhoid fever and tularemia in man. IV. The integrity of the endotoxin tolerance mechanisms during infection. J Clin Invest 1969;48:613-29.

2. Cannon JG, Tompkins RG. Gelfland JA, et al. Circulating interleukinI and tumor necrosis factor in septic shock and experimental fever. J Infect Dis 1990;161:79-84.

3. Hack CE. De Groot ER, Felt-Bersma RJF, et al. Increased plasma levels of interleukin-6 in sepsis. Blood 1989;74:1704-10.

4. Mitchie HR, Spriggs DR, Manogue KR, et al. Tumor necrosis factor and endotoxin induce similar metabolic responses in human beings. Surgery 1988: 104:280-5.

5. Okusawa S. Gelfland JA. Ikejima T, Connolly RJ, Dinarello CA. Inter- leukin- 1 induces a shock-like state in rabbits. Synergism with tumor necrosis factor and the effect of cyclooxygenase inhibition. J Clin Invest 1988;81:1162-72.

6. Fischer E, Marano MA, Barber AE, et al. Comparison between effects of interleukin-l $\alpha$ administration and sublethal endotoxemia in primates. Am J Physiol 1991;261:R442-52.

7. Calandra T, Baumgartner JD, Grau GE, et al. Prognostic values of tumor necrosis factor/cachectin, interleukin-1, interferon- $\alpha$, and interferon- $\gamma$ in the serum of patients with septic shock. J Infect Dis 1990;161:982-7.

8. Damas P, Reuter A, Gysen P, Demonty J, Lamy M, Franchimont P. Tumor necrosis factor and interleukin-1 serum levels during severe sepsis in humans. Crit Care Med 1989;17:975-8.

9. Waage A, Brandtzaeg P. Halstensen A, Kierulf P. Espevik T. The complex pattern of cytokines in serum from patients with meningococcal septic shock. Association between interleukin-6, interleukin-1, and fatal outcome. J Exp Med 1989;169:333-8.

10. Grau GE, Fajardo LF, Piguet PF, Allet B, Lambert PH, Vassalli P. Tumor necrosis factor (cachectin) as an essential mediator in murine cerebral malaria. Science 1987:237:1210-2.

11. Barnes PF, Chatterjee D, Brennan PJ. Rea TH, Modlin RL. Tumor necrosis factor production in patients with leprosy. Infect Immun 1992;60: 1441-6.

12. Havell EA. Production of tumor necrosis factor during murine listeriosis. J Immunol 1987; 1 39:4225-31.

13. Liew FY, Parkinson C, Millot S. Severn A. Carrier M. Tumor necrosis factor (TNF) in leishmaniasis I. TNF mediates host protection against cutaneous leishmaniasis. Immunology 1990;69:570-3.

14. Nakane A. Minagawa T, Kato K. Endogenous tumor necrosis factor (cachectin) is essential to host resistance against Listeria monocytogenes infection. Infect Immun 1988;56:2563-9.

15. Silva CL, Foss NT. Tumor necrosis factor in leprosy patients. $\mathbf{J}$ Infect Dis 1989;159:787-90.

16. Titus RG, Sherry B, Cerami A. Tumor necrosis factor plays a protective role in experimental murine cutaneous leishmaniasis. J Exp Med 1989; 170:2097-104

17. Nakano Y, Onuzuka K. Terada Y. Shinomiya H, Nakano M. Protective effect of recombinant tumor necrosis factor- $\alpha$ in murine salmonellosis. J Immunol 1990; 144:1935-41.

18. Nauciel C. Espinasse-Maes F. Role of $\gamma$ interferon and tumor necrosis factor- $\alpha$ in resistance to Salmonella typhimurium infection. Infect Immun 1992;60:450-4.

19. Tite JP, Dougan G, Chatfield SN. The involvement of tumor necrosis factor in immunity to Salmonella infection. J Immunol 1991:147:3161-4.

20. Peel JE, Voirol MJ, Kolly C, Gobet D, Martinod S. Induction of circulating tumor necrosis factor cannot be demonstrated during septicemic salmonellosis in calves. Infect Immun 1990;58:439-42.

21. Roine I, Herrera $P$, Ledermann W, Peltola $H$. Tumor necrosis factoralfa (TNF- $\alpha$ ), interleukin- I-beta (IL-I $\beta$ ) and interleukin-6 (IL-6) levels in typhoid fever (TF) [abstract 299]. In: Program and abstracts of the 30th Interscience Conference on Antimicrobial Agents and Chemotherapy (Atlanta). Washington, DC American Society for Microbiology, 1990.

22. Butler T, Ho M, Acharya G, Tiwari M, Gallati H. Interleukin-6, gamma interferon and tumor necrosis factor receptors in typhoid fever related to outcome of antimicrobial therapy. Antimicrob Agents Chemother 1993;37:2418-21.

23. van Deuren M, van der Ven-Jongekrijg J, Keuter M, Demacker PNM van der Meer JWM. Cytokine production in whole blood cultures. J lnt Fed Clin Chem 1993:5:216-21.

24. Nerad JL, Griffiths K, van der Meer JWM, et al. Interleukin-1 $\beta$ (IL- 
$1 \beta$ ). IL-1 receptor antagonist and TNF $\alpha$ production in whole blood. J Leukoc Biol 1992;52:687-92.

25. van der Meer JWM, Endres S, Lonnemann G, et al. Concentrations of immunoreactive human tumor necrosis factor alpha produced by human mononuclear cells in vitro. J Leukoc Biol 1988:43:216-23.

26. Lisi PJ. Chu CW, Koch GA. Endres S. Lonnemann G, Dinarello CA. Development and use of radioimmunoassay for human interleukin13. Lymphokine Res 1987:6:229-44.

27. Barrera P, Boerbooms AMT, Janssen EM, et al. Circulating soluble TNF receptors and interleukin- 2 receptors, tumor necrosis factor- $\alpha$ and interleukin- 6 in rheumatoid arthritis. Longitudinal evaluation during methotrexate and azathioprine therapy. Arthritis Rheuma 1993:36:1072-9.

28. Poutsiaka DD, Clark BD, Vannier E, Dinarello CA. Production of interleukin- 1 receptor antagonist and interleukin- $1 \beta$ by peripheral blood mononuclear cells is differentially regulated. Blood 1991:78:1275-81.

29. Dinarello CA. Interleukin- 1 and interleukin-I antagonism. Blood 1991:77:1627-52.

30. Shapiro L, Clark BD, Orencole SF. Poutsiaka DD. Granowitz EV, Dinarello CA. Detection of tumor necrosis factor soluble receptor $\mathrm{p} 55$ in blood samples from healthy and endotoxemic humans. J Infect Dis 1993:167:1344-50.

31. Luger A. Graf H, Schwarz HP, Stummvoll HK, Luger TA. Decreased serum interleukin $I$ activity and monocyte interleukin $I$ production in patients with fatal sepsis. Crit Care Med 1986;14:458-61.

32. Simpson SQ, Modi H, Balk RA. Bone RC, Casey LC. Reduced alveolar macrophage production of tumor necrosis factor during sepsis in mice and man. Crit Care Med 1991:19:1060-6.

33. Srugo I. Berger A. Lapidot Z. Katz R. Pollak S. Interleukin-l secretion by blood monocytes of septic premature infants. Infection 1991:3:150-4
34. Helminen M. Interleukin-1 production from peripheral blood monocytes in septic infections in children. Scand $J$ Infect Dis 1991:23:607-11.

35. Rozenbaum M, Katz R, Rozner I, Pollack S. Decreased interleukin I activity released from circulating monocytes of patients with familial Mediterranean fever during in vitro stimulation by lipopolysaccharide. J Rheumatol 1992;19:416-8.

36. Schattner A, Lachmi M, Livneh A, Pras M, Hahn T. Tumor necrosis factor in familial Mediterranean fever. Am J Med 1991;90:434-8.

37. Endres S, Cannon JG, Ghorbani R, et al. In vitro production of IL- $1 \beta$, IL- $1 \alpha$, TNF $\alpha$ and IL-2: distribution, effect of cyclooxygenase in hibition and evidence of independent gene regulation. Eur J Immunol 1989;19:2327-33.

38. Schindler $R$, Mancilla $J$, Endres $S$, et al. Correlations and interactions in the production of interleukin-6 (IL-6), interleukin-1 (IL-1) and tumor necrosis factor (TNF) in human blood mononuclear cells: IL-6 suppresses IL-1 and TNF. Blood 1990;75:40-7.

39. Vannier E, Miller LC, Dinarello CA. Coordinated antiinflammatory effects of interleukin-4: interleukin-4 suppresses interleukin-1 production but upregulates gene expression and synthesis of interleukin1 receptor antagonist. Proc Natl Acad Sci USA 1992;89:4076-80.

40. Dinarelio CA. Cannon JG, Mancilla J, Bishai 1, Lees J, Coceani F. Interleukin- 6 as an endogenous pyrogen: induction of prostaglandin E2 in brain but not in peripheral blood mononuclear cells. Brain Res 1991;562:199-206

41. Waage A, Brandizaeg P, Halstensen A, Kierulf P, Espevik $T$. The complex pattern of cytokines in serum from patients with meningococcal septic shock. Association between interleukin- 6 , interleukin-1 and fatal outcome. J Exp Med 1989;169:333-8.

42. Van Damme J. Interleukin-8 and related molecules. In: Thomson AW, ed. The cytokine handbook. London: Academic Press, 1991. 